\title{
Focus
}

\section{De ongetemde God: stilstaan bij Gods wezen en eigenschappen}

\author{
R.T. te Velde
}

Matthew Barrett, None Greater: The Undomesticated Attributes of God

(Grand Rapids: Baker, 2019), 304 p., € 14,99 (ISBN 9780801098741).

Onder de titel 'None Greater: The Undomesticated Attributes of God' schreef Matthew Barrett een toegankelijk overzicht van de klassieke leer over Gods wezen en eigenschappen. Barrett doceert theologie aan het Midwestern Baptist Theological Seminary in Kansas City, Missouri, Verenigde Staten. Onder baptistische theologen is een opmerkelijke toenadering gaande tot de klassiek-gereformeerde theologische traditie, en Barrett is daar een duidelijke exponent van.

De reden om dit boek in de schijnwerpers te zetten is niet zozeer de originaliteit of wetenschappelijke kwaliteit ervan. De weergave en analyse van de besproken onderwerpen zijn solide en maken gebruik van de voornaamste wetenschappelijke literatuur. Daarbij mikt Barrett op een algemeen publiek van theologisch geschoolden en geïnteresseerden. Het betoog is doorspekt met voorbeelden en anekdotes om de soms abstracte argumentatie dichterbij te brengen. Een aardige vondst is het presenteren van 'The A-team': drie grote theologen die het denken over God gestempeld hebben. Hun namen beginnen met een A: Augustinus, Anselmus, en Aquino (Thomas, dus). Dit herinnert mij aan de prominente AA-lijn die in Utrecht door dr. Antoon Vos werd geschetst als hoofdlijn van het christelijke denken; ook die lijn begint met Augustinus en Anselmus, maar gaat dan verder met Johannes Duns Scotus en andere franciscaanse denkers in plaats van met Thomas van Aquino.

Het belang van Barretts boek zie ik in de context van de bredere discussie die in de Noord-Amerikaanse theologie gaande is tussen 'classical theism' en 'theistic mutualism'. Klassiek theïsme is de leer over God die sinds de kerkvaders tot en met de protestantse scholastiek van de zestiende tot achttiende eeuw is ontwikkeld tegen de achtergrond van een aristotelische metafysica en met behulp van begrippen die uit het Grieks-filosofische denken pasklaar gemaakt werden in de middeleeuwse scholastiek. Belangrijke belijdenisge- 
schriften zoals de Nederlandse Geloofsbelijdenis (artikel 1) en de Westminster Confessie (hoofdstuk 2) hebben deze Godsleer in beknopte vorm overgenomen. Wanneer het in de huidige discussie over 'klassiek theïsme' gaat, wordt daarmee niet alleen een kerkelijk leerstuk bedoeld, maar is ook de argumentatieve, filosofische onderbouwing daarvan in beeld. Hiertegenover ontwikkelt zich de laatste decennia in de Verenigde Staten een alternatieve visie, die wil breken met de als schadelijk en achterhaald beschouwde metafysica van het klassiek theïsme, en een omschrijving van Gods wezen en eigenschappen bepleit op basis van Gods openbaring als de God van het verbond. Bekende pleitbezorgers van deze wending zijn John M. Frame, K. Scott Oliphint en Bruce A. Ware. Zij menen dat er bij de 'relationele' of 'verbondsmatige' eigenschappen van God sprake is van een zekere wederkerigheid tussen God en zijn schepselen; vandaar de aanduiding 'theistic mutualism'. Sinds de jaren 1980 heeft deze laatste stroming het tij mee, maar de laatste jaren ontstaan er heftige debatten over de invulling van Gods eigenschappen zoals 'eenvoudigheid' (simplicitas), 'onveranderlijkheid' (immutabilitas) en 'onlijdelijkheid' (impassibilitas).

Matthew Barrett gaat niet of nauwelijks rechtstreeks op deze debatten in. Juist dat maakt zijn pleidooi voor het klassieke verstaan van Gods wezen en eigenschappen waardevol voor theologen in Nederland, waar de discussie gelukkig niet zo gepolariseerd is als aan de overkant van de oceaan, maar waar wel vergelijkbare ontwikkelingen in het denken over God zich hebben voltrokken. De waarde van het boek None Greater zie ik op met name drie punten.

Ten eerste laat Barrett overtuigend de innerlijke samenhang zien van het klassieke spreken over God. Niet iedereen zal van zulke consistentie meteen onder de indruk zijn; in onze postmoderne setting denken we eerder in fragmenten dan in grotere gehelen. En de samenhang krijgt in de traditionele Godsleer soms - ook bij Barrett - de vorm van een wat vermoeiende cirkelredenering. Toch gaat het wel om een waardevol inzicht. De eigenschappen die we aan God mogen toeschrijven - op grond van hoe Hij zichzelf bekendmakkt - zijn geen losse verzameling, en we kunnen ook geen scheiding maken tussen 'bijbelse' en 'filosofische' eigenschappen. Op dit niveau bevat het klassiek theïsme zoals Barrett het presenteert een belangrijke les: denk niet te snel dat je klaar bent met het denken en spreken over God. De oneindige rijkdom van Gods wezen vraagt om diepe doordenking, voorbij datgene wat op het eerste gezicht uit de Schrift af te lezen is. Uit persoonlijke ervaring vertelt Barrett hoe het 'Godsbegrip' van de traditie - naast Augustinus en Thomas noemt hij ook Calvijn, Charnock en Bavinck - hem trof als veel rijker, confronterender en troostrijker dan de verdunde therapeutische versie die in evangelicale kringen gemeengoed was geworden. 
Met de titel None Greater verwijst Barrett naar de traditie van 'perfect being theology': de benadering van God als het meest volmaakte, hoogste wezen, met daaraan verbonden een uitleg van de 'grootmakende' eigenschappen die bij God passen. Wat velen op deze onderneming tegen hebben, is de suggestie alsof wij, mensen, kunnen uitmaken wat voor God 'volmaakt' of 'grootmakend' is. Er is echter een andere route: Gods eigen openbaring in de Heilige Schrift geeft ons alle aanleiding om over de grootheid van de HEER na te denken, en dat mag in alle richtingen en facetten. Deus semper maior God is altijd groter. Dat mag ons bij het nadenken over wie God is wel voortdurend voor de geest staan. Dit besef wordt echter onvoldoende geëerd wanneer wij voortijdig ophouden ons over de grootheid van God te verwonderen en die van alle kanten te doorlichten. Dezelfde traditie die van schatplichtigheid aan filosofische begrippen ('Grieks denken!') wordt beticht, hield strikt vast aan het inzicht dat God in geen van onze categorieën op te sluiten is (in woorden van Thomas van Aquino: Deus non est in genere, God is niet als een 'soort' te beschrijven). Dit betekent niet dat we onze denkcategorieën angstvallig bij God uit de buurt moeten houden, maar dat we deze begrippen opnieuw laten bepalen door God die ze principieel overstijgt.

Op dit punt is er een dubbele inhaalslag te maken. Allereerst als het gaat over het inzicht dat God niet in onze begrippen past (non in genere). Kritische theologen betrekken dat vaak op de systematiek van 'substantie' en 'accidenten' die aan de filosofie van Aristoteles is ontleend. Hetzelfde geldt echter voor de denkcategorieën die momenteel onze voorkeur hebben: persoon, relatie, gebeuren, communicatie. Soms wordt er als vanzelf van uitgegaan dat hedendaagse denkwijzen beter aansluiten bij en rechtdoen aan de dynamiek van de bijbelse openbaring. Ook hierbij moeten we echter het semper maior bedenken. Het genus 'relatie' met alle kwalificaties die we eraan kunnen geven, is niet per definitie geschikter om te omschrijven wie God is dan het oudere taalkader.

De tweede inhaalslag zie ik naar een andere kant. Het klassiek theïsme lijkt soms te bestaan in een redelijk simpel, schematisch contrast tussen God en ons. Ook bij Barrett gaat het weleens zo vlot: God is oneindig, wij zijn eindig; God is onafhankelijk, wij afhankelijk; God is eeuwig, wij bestaan in de tijd. Op een diep niveau is dat waar en onopgeefbaar. Toch geloof ik dat er iets mis gaat wanneer we alleen in die tegenstelling denken. We moeten dan alles van onszelf wegdenken om bij God uit te komen. Is er over ons als mensen geschapen naar Gods beeld - niet meer te zeggen wat ook een zekere verbinding en continuïteit toelaat? Om een voorbeeld te geven: wanneer we over de eeuwigheid van God spreken, ontdekken we hoe momentaan en vluchtig ons eigen bestaan is. Toch staat daar ook het woord van Prediker 3:11: 'ook heeft 
Hij de eeuw in hun hart gelegd' (vertaling NBG-1951). Prediker geeft meteen de grens aan: de mens kan het werk van God niet van begin tot eind overzien. Toch is juist dit typerend en onderscheidend voor de mensen, dat wij wel degelijk een tijdsspanne kunnen omvatten, dat wij historisch besef hebben, onszelf kunnen plaatsen in de tijd, verband kunnen leggen tussen vroeger en later, en ons verbonden voelen met mensen van tijden en plaatsen ver bij ons vandaan. Als er continuïteit is tussen hoe God bestaat en hoe mensen bestaan, dan is het geschonken continuïteit: wij kunnen ons niet op eigen benen tegen de Schepper verheffen. Toch is het juist zijn eer als Schepper om van zijn eigen goedheid iets terug te zien in het maaksel van zijn handen. Zoals Psalm 104:31 (NBV) het bezingt: 'Laat de HEER zich verheugen in zijn werken'. Met andere woorden: een rijke leer over God roept ook een gevulde leer over de mens en de schepping op. Als wij alleen in negatieve termen spreken over de verhouding van Schepper en schepsel, doet dit aan wie God is geen recht.

Het tweede dat opvalt aan None Greater is het hoge gehalte aan bijbels materiaal. Vanuit de populaire tegenstelling tussen 'bijbels' en 'filosofisch' zou je wellicht anders verwachten. Matthew Barrett laat zien dat de klassieke Godsleer breed en diep in de bijbelse openbaring verworteld is. Het geheel van de 'eigenschappen' die traditioneel aan God worden toegeschreven, is niet maar op losse teksten gefundeerd, maar weerspiegelt het doorgaande getuigenis van de Schrift. Op soms verrassende wijze laat Barrett uit een bijbels verhaal of uit een Psalm oplichten hoe een of meer van Gods deugden aan de orde is/zijn. Een mooi voorbeeld is hoofdstuk 7, over de vraag of God emoties heeft. Uitgebreid komt daar de geschiedenis van Bileam naar voren, die door de Moabitische koning Balak was ingehuurd om het volk Israël te vervloeken. In het 'godsbeeld' dat Balak en Bileam gemeenschappelijk hebben, lijkt het normaal dat de godheid zich laat plooien naar de behoeften van de opdrachtgever. Bij Israëls God gaat dit niet op: in Numeri 23:19-20 (NBV) laat de HEER bij monde van Bileam van zich horen, en dan blijkt hoe uniek Hij is:

'God is geen mens, dat hij zijn woord zou breken of terug zou komen op zijn besluit.

Zou hij beloven en niet vervullen, zijn woord geven en het niet gestand doen?

Hij droeg mij op te zegenen.

Hij heeft gezegend - kan ik dat keren?'

De HEER is niet emotioneel manipuleerbaar. Toch betekent dit niet dat Hij kil en onbewogen is: in zijn goddelijke onveranderlijkheid komt Hij op voor 
het volk dat Hij uit Egypte leidde; Hij is voor hen als de horens van een wilde stier' (Numeri 23:22, NBV).

Dit aspect van Barretts boek bevat een belangrijke methodische en hermeneutische les. De Kamper hoogleraar Nieuwe Testament dr. Jakob van Bruggen sprak bij de uitleg van de paulinische brieven over het 'grondwater' van de apostolische prediking: behalve de expliciete uitspraken die Paulus in concrete situaties doet, moet je ook alert zijn op wat daarin 'ondergronds' meekomt aan overtuigingen over God en zijn heil in Jezus Christus. Dit geldt voor heel Gods zelfopenbaring: niet alles hoeft expliciet gemaakt te worden, om toch als vanzelfsprekend mee te komen in wat God van zichzelf laat zien of laat horen. Soms worden zulke implicaties pas duidelijk wanneer je achteraf naar het geheel van de bijbelse geschiedenis kijkt, en ontdek je dan ook hoe zulke inzichten en samenhangen worden aangeduid in teksten die er op het eerste gezicht niet over gaan.

Een derde belangrijk element is de koppeling die Barrett aanbrengt tussen de leer over God en de leer van het verbond. Zoals gezegd gaat None Greater niet expliciet de discussie aan met auteurs als K. Scott Oliphint, die in enkele recente publicaties (met name zijn boek God with Us: Divine Condescension and the Attributes of God, Wheaton: Crossway, 2011) heeft verdedigd dat God niet alleen 'essentiële' eigenschappen heeft maar ook 'verbondsmatige' eigenschappen: kwaliteiten die God alleen kan hebben in het kader van zijn verbondsmatige omgang met mensen, zoals toorn en geduld. Intuïtief spreekt dit aan: als God relationeel is in zijn diepste wezen, dan lijkt dit de ultieme garantie dat we op Hem aankunnen wanneer Hij zich aan ons wil verbinden. Blijft in het klassieke denken de reële betrokkenheid van God op de wereld en de mensen niet te extern? Hier liggen spannende vragen. Wanneer Matthew Barrett bijvoorbeeld zo lyrisch spreekt over God als 'pure act' (actus purus: er is in God geen ongerealiseerd potentieel, maar Hij is alles wat Hij is ten volle), vraag je je af of hierin helemaal geen concretisering en differentiatie mogelijk zijn. Dat God mij hier en nu kent en liefheeft, valt dat helemaal weg tegen de achtergrond van zijn eeuwige wezen?

Toch slaagt Barrett erin een diepere laag aan te boren. De 'klassieke' eigenschappen vormen niet een bedreiging voor de concrete realiteit van Gods verbondsmatige omgang met mensen, maar maken die pas echt mogelijk en staan garant voor de duurzame kwaliteit ervan. Juist het feit dat God niet opgaat in zijn verbintenis met mensen is goed nieuws: Hij heeft altijd meer te bieden, zijn reservoir aan liefde en zijn vermogen om met die liefde ons te bereiken zijn nooit uitgeput. Als het bij ons stukloopt, kan God altijd verder, omdat Hij 'redenen uit zichzelf neemt'. Dat God altijd een nieuw begin kan 
maken in de relatie met zijn volk, is een directe consequentie van zijn 'hoogheids'-eigenschappen (deze term gebruikt de Christelijke Dogmatiek van G. van den Brink en C. van der Kooi). In het tweede gedeelte van Jesaja komt dit op indrukwekkende wijze naar voren. Juist in zijn 'grootmakende' eigenschappen is de HEER uniek, boven alles verheven en boven alles te beminnen. Hierin verschilt God wezenlijk van de afgoden, die passen in wat wij wensen of bedenken kunnen. Met een 'god' in zakformaat ben je snel uitgepraat. Met de God van Israël, die met niets of niemand te vergelijken is (Jesaja 40:18), gaat de weg altijd verder.

Dat God op zijn eigen, unieke wijze het verbond met ons aangaat, doet dus niets af aan de realiteit van de omgang, maar geeft een unieke diepgang, kwaliteit en bestendigheid aan de relatie. 'Vriendschap met de Eeuwige is eeuwige vriendschap' - deze uitspraak wordt aan zowel Okke Jager als H.M. Kuitert toegeschreven, en ik leerde haar kennen bij het vroegtijdig overlijden van mijn studiegenote Rolinda Both. God overstijgt verre ons bestaan en ons verstand. Dit maakt zijn trouw zo onverbrekelijk en zijn liefde zo intens. Voor gereformeerde theologie vandaag is er alle reden om zuinig te zijn op de elementen uit het klassieke denken over God die ons hierop wijzen. Met een voorbeeld maakt Matthew Barrett duidelijk waar het hier om gaat: als je huis in brand staat heb je meer aan een brandweerman die met opzijzetten van angst en medelijden naar binnen gaat om je achtergebleven kind te redden, dan aan iemand die met je meehuilt omdat het zo vreselijk is. ${ }^{1}$ Een van mijn studenten in Kampen voelde dit goed aan toen hij - weliswaar zonder een aantal noodzakelijke nuanceringen - aangaf dat de 'onbewogen Beweger' voor hem zo belangrijk is, omdat deze God wel tegen een stootje kan. In reactie op een soms wat te sentimentele manier van spreken over God, die Hem wel dichtbij brengt maar ook wat machteloos maakt, kan het geen kwaad om het 'geheel anders' van God opnieuw naar voren te halen. Daar slaagt Matthew Barrett wat mij betreft goed in.

De sleutel voor een gezonde leer over God is de triniteitsleer. Alleen wanneer ons denken en spreken over God sporen met zijn openbaring als de Drieenige, kunnen we hopen iets waars en waardevols over God te zeggen. In enkele mooie passages laat Barrett zien dat de klassieke Godsleer niet wringt met de belijdenis van Gods drie-eenheid, maar daar juist diep mee verbonden

1 Dat hier meer aan vastzit, wordt duidelijk uit het tweetal artikelen van H.G.L. Peels, 'Tranen in Gods ogen: De keerzijde van het oordeel in het boek Jeremia' en A. Huijgen, 'Alleen de God met tranen in de ogen kan helpen: Systematisch-theologische reflecties bij weerbarstige teksten uit de profetie van Jeremia', Theologia Reformata 62/2 (juni 2019), 135-148 en 149-161. 
is en eruit voortvloeit. Dit geldt bijvoorbeeld voor Gods onafhankelijkheid en eenvoudigheid, maar ook voor zijn liefde en zijn alwetendheid. Omdat God in zichzelf de volheid van leven is (vgl. Johannes 5:26), kan Hij vanuit die volheid ons zijn liefde schenken zonder van ons afhankelijk te worden. 